\title{
Meritocracy - The Only Criterion to have a Professional Public Administration in the Civil Service
}

\author{
Dr. Gaqo Tanku \\ Lecturer at "Aleksandër Moisiu" University, Durrës \\ Msc. Shkelzen Imeri \\ Diplomat, Ministry of Foreign Affairs
}

\section{Doi:10.5901/mjss.2014.v5n6p165}

\section{Abstract}

This paper deals with appointments in public administration, as one of the frontline pillars of state foundation. After theoretical considerations, this article gives ideas and proposes solutions focusing on appointments and why in this moment the meritocracy is more important than anything. This essay tries to answer the following questions: Why is meritocracy important? Who are the integral components of meritocracy? How do you define it? Why proper structures do not pay much attention to meritocracy? How to extend its use? Another focus of this article is the concern on patronage and meritocracy concept, how to distinguish between them in daily practice. In such circumstances and especially on this moment of the Albanian state, it is important undertaking reforms for some change, not only to implement the law regarding appointments in the public administration but something more than that.

Keywords: meritocracy, public administration, patronage, corruption, political patronage, nepotism.

\section{Introduction}

Regarding the transformations after 90s, primary object was the adoption of the civil service law. For the first time it was adopted in 1995-1996, with aproval of the first law of civil service (Law no. 8095/1996). Although this law was not enforced, in 1998 institutional reform and civil service of the government regained attention of Governement and was aproved a new act of the Civil Service Law (Law no. 8549/1999).

Although the law was in accordance with the standards and principles more widely accepted by European countries, its principles were not fully embraced by the relevant political and administrative Albanian actors. Later, legislation was supplemented with detailed acts of the legislation; DAP (central unit of policy and management) as well as the Civil Service Commission were strengthened (which reports to Parliament), and were set up to deal with complaints resolution functions and oversight for the implementation of legislation in the civil service.

After a first period of moderate success, at the beginning of the development of a professional civil service and improvement of the quality of public administration work, further progress in civil service reform as well as implementation of civil service legislation proved to be difficult, unsustainable and that "remained problematic"1.

In view of the transformation process adopted in 1995-1996, the main problems identified can be summarized as follows:

1. Recruitment is not based on merit (mainly due to the use of temporary contracts and the lack of transparency and accountability in appointments.

2. Politicization and instability (reflected in "politically motivated movement ${ }^{2}$.

3. Poor Management and control over implementation of the civil service law.

In these conditions the proper structures have accepted the problems and the need for a professional civil service, impartial and efficient, and the importance of civil service reform. Its goals are to increase the capacity of the state to continue reforms in the country's development, modernization of economy and society, the preparation for EU association and further to full membership.

Inter-Sectorial Strategy of Public Administration Reform (SNRAP) 2009-2013 envisioned the establishment of a

${ }^{1}$ Komunikimi nga Komisioni në Parlamentin Evropian dhe Këshillin "strategjia e zgjerimit dhe sfidat kryesore 2009-2010

2 Draft Dokumenti Konceptual mbi mbi një ligj të ri për shërbimin civil në Shqipëri, Zhani Shaqo, Dr.Hans Achim Roll, 1 Teor 2010. 
professional civil service, sustainable, effective and responsibel, as one of its three strategic objectives. SNRAP identifies the need to prepare a new law on civil servant aimed at improving and aligning the civil service system with European standards and best practices in the following areas:

a) strengthening the unity and homogeneity of the regime of civil service employment;

b) strengthening the principle of merit in recruitment;

c) increase the mobility and career development within the civil service,

d) improving the training system.

\section{Public Appointments: The Way to Meritocracy}

Imagine a world where the best ideas have the opportunity to implement successfully. There is no favoritism towards people who are not eligible for a new project, there is no place for brokers who recommend arbitrarily impaired people without proper skills, which are a cost for the organization to the one that with his/her talent fully deserves. Forget the nepotism of organization that appoints leaders based on relationships outside of meritocracy.

Any individual, group and industry will benefit from a world where the most talented people have good oportunities to exercise their talents. This dream is called "creative meritocracy", and we believe that the progress of technology and platforms that enable the career independently, will make this dream a reality in the near future ${ }^{3}$.

Unfortunately, we face with instilling hostile practices at all opportunities based on merit criteria. In many organizations and society as a whole, very often faces with tainted intermediaries and systems that determine quality. It is a truth that must be accepted: Quality of ideas and talent is sometimes less important than what you know or the person who represents you and the name that you have. Why? Because the old system is still among us. Refering to Oxford Dictionary, ) ${ }^{4}$ Meritocracy-is rule by elites, which deserve to use power for own meritocracy (defined as intelligence plus effort) instead of those who simply possess wealth or belonging to the privileged classes. Meritocracy is similar to democracy, but by adding a very important point. While accepted the value of full participation in society, it also defends the importance of the hierarchy of meritocracy in the political and social landscape. It is a system that emphasizes that society should be structured around the possibility of human structure and not on how rich or aristocratic privileges do they have. Under scrutiny, you can see that the money and the wrong use of power, historically has been the force that has defined hierarchies within democratic societies. For instance, people who possess a lot of financial resources are given great opportunities and mechanisms in shaping public policy in support of their own interests. This has led to classbased differences in wealth than in knowledge and character. Meritocracy eliminates this stream, as happens nowadays in develompent democratic societies.

Furthermore, meritocracy ends of the racial discrimination or religious. In a system based on meritocracy, the ability of a person (and determination to implement it) is the cornerstone that determines the impact on his / her.

Philosophical orientation which is based on meritocracy (and taken more into consideration) uses intellectual powers and personality, as a leading indicator for determining the merit of the individual (and his status in society). In one sense this is based on Darwinian model of evolution. It is somehow motto of "survival of the fittest" in the social and political context.

It is possible to discuss a particular form of corruption which occurrence very often through abuse in public administration appointments. First let's look on the definition: Corruption is the abuse of power that is entrusted in order to ensure private benefits. Every citizen is harmed by the lack of integrity of the person who is in an official position) 5 .

Theoretically there are two manifestation forms of manifestation of abuse and corruption in public appointments:

A. Individuals pay money to take a job. This form is known as bribery to be employed.

B. Officials put friends, relatives or political supporters in public work place, which could not be reached without their intervention ("patronage"). We emphyses that there are discussions about this phenomenon in our society everywhere.

This form although is not associated with graft material (financial) is very disturbing and is known as "patronage" (So assuming someone defensively). It is a fact nearly $90 \%$ of trials in the court regarding the public administration has been lost in litigation) ${ }^{6}$.

What happens if you do not implement the principle of equality in the selection or when it is an undeserved

\footnotetext{
${ }^{3}$ Welcome to the Era of Creative Meritocracy, Scott Belsky. 99u.com/articles.

${ }^{4}$ Oxford University Press. Retrieved 12 September 2011

5 (www.transparency.org

${ }^{6}$ raporti $i$ komisionit të shërbimit civil në kuvend-mars 2012
} 
promotions? Is there nepotism in organizations? Are there consequences of this phenomenon? Usually the answer is yes, but first let's looks at the definition of nepotism, which is considered almost the antipodes of "meritocracy". This word derives from a Latin root (grandchild, niece, and neighbor). In dictionaries of different countries is defined as "corruption", but it can be defined in an administrative sense, usually has to do with phenomena, which met in those entities where the level of democratization is low. These "entities" may be an expression of the level of development of society, but in certain cases, different individuals may interfere with the rules of the "merit" system by implemented "nepotism" system, through which can provide a kind of micro-cultures "rule" that existed before and belong to this entity micro-cultures or specific country ${ }^{?}$.

In a working environment, where reward and promotion are based on nepotism, employees are less willing to perform their work. The morale of organizations are going down as well as their effectively. Employees are unhappy and tend to move toward other organizations. In other words, it's when the organization risks losing its potential effectiveness. Nepotism threat the quality of being 'right' in the treatment of employees, creates a barrier to the market to attract skilled manpower. Another problem is skills that will provide the employee. This is the most sensitive at the positions that requiring a higher level of candidate. There is possible to take an example in public sector organizations. Managers often put on key positions their relatives or friends and it doesnt matter what capacity they have. This simply means that they can keep the situations under the control as well as they can say "yes sir" at any time. Also do not missing reciprocal favors by taking a significant position. The Albanian press has not missed to publish facts about the phenomenon of nepotism in various structures of the state, universities, private organizations, etc ${ }^{8}$. The legal aspect is another part of nepotism. Organization threatens to be on the court due to discrimination in the selection process of candidates or favored treatment in the workplace. Due to the fact that nepotism affects many areas such as employment, culture of the organization, evaluation, promotion, it is the duty of HR to address this issue and find ways to minimize this problem. Today the concept of meritocracy and nepotism has wide dimensions. Studies indicate that U.S. companies rely more on meritocracia compared with European ones, where nepotism is present. The American system is an example of the ideology of unlimited possibilities, where the individual can move forward on the basis of his merit. Individual merit is regarded as a combination of innate ability, hard work, proper dignity as well as having a strong moral character and integrity.

Nowadays it is widely accepted so called Network or social network. Often this network is one of the best resources to open doors in the labor market. The reasons are very simple: there we have invested; we are accepted and have a preliminary knowledge base. From the employer's standpoint, this is a good source and secures employment. When you know someone or when you have a good reference, it increases the reliability of a good recruiting against someone to whom you can read a CV, or evaluate through test or interview. Employing workers through social network can function very well, if we decide to work and treat each other on the basis of merit and fairness. In terms of involvement of relatives in private small businesses, we can create more stability and sustainability. In this context, it is a positive aspect of nepotism. The family business has durability because its members are dedicated, have emotional ties and common purpose.

\section{The Perspective of "Patronage"}

According to Robinson (1998), ${ }^{9}$ we can distinguish two main directions in developing countries. The first perspective is that of economists. According to them corruption is a species that requires money out of legal forms. Economists tend to reduce opportunities for corruption, by reducing the government control on the economy. Other economists see the roots of corruption in the centralization of governmental functions to a single agency, which creates opportunities for officials to maximize their profits illegally. In order to reduce corruption they recomend to set up strict rules to reduce the maximum benefits. In these conditions, they call for growth and expansion of the powers of other state agencies that can check each other. The only way to reduce financial corruption or public appointments, is drastically reducing the role of government in the economy, says Gary Becker ${ }^{10}$. This means to reduce or privatize many of the functions that are still in the "hands" of government structures.

The second perspective comes from political science. From this perspective, this type of corruption is due to the

\footnotetext{
${ }^{7}$ Global Strategic Management, Philippe Lasserre, Palgrave Macmillan Limited, 2003

8 (Krasniqi, gazeta shekulli, dt.23.08.2012

${ }^{9}$ Robinson., M. (1998) 'Corruption and development: An introduction', in M. Robinson (ed.), Corruption and development. London: Frank Cass, 1-14.

10 Gary Becker-1998:quoted in Galtung
} 
lack of political stability and political competition, as well as the result of a weak civil society which is underdeveloped. We are witness of the dismissal from work because of changing power, although for this purpose there is a special law. On the other hand, we are witness of little reaction by the civil society to these phenomena. The fact mentioned at the beginning of the paper where nearly $90 \%$ of trials in the court regarding the public administration were lost.

Although by law the political positions are separated by administrative posts, political parties reach agreement that $\mathrm{x} \%$ of posts will have one and $\mathrm{y} \%$ the other party. In this way they violate the law that was adopted by them, while positions at the director level are administrative and not political post. This drives the need for a strengthening of the institutions and mechanisms of the "voice" by civil society.

The third view comes from another branch of social science, from psychology and specifically by organizational psychology, ${ }^{11}$ which has developed useful techniques for predicting the performance of work for example the skills tests, assessment centers and improvements traditional interviewing panels. The current law has many shortcomings in this regard. My Personal Experience tells me that in general competitions of recruitment this process is not going in the right way. Usually the winner is the person that have sighn the temporary contracts. In such circumstances it is very important to close once and for all such practices as well as widely use the above techniques.

\section{Why Meritocracy is Important?}

Appointments in the public administration are very important, but officials often fail to take into consideration the merit criteria. We judge that there are four reasons why the recruitment is an important element of public administration reform.

1. EU integration requires that public administration must be based on merit criteria.

2. The fight against corruption is one of the 12 priorities for obtaining the status of candidate country to the EU. Appointments based on merit criteria, is a cornerstone of strategy to fight against corruption. While stating that there are strategy for fighting corruption, yet in practice there are no tangible results that the civil society is waiting.

3. Strong correlation between the best methods of selecting staff and staff whose mission is to use them during selection.

4. Current system implements superficial selection of public administration, and increases even more rumors about people who are appointed to office.

In implementing the merit criteria on appointments in public administration from top to down, every candidate must be recruit through meritocracy rules, which have been made public, and publicly understood as well as they have to be challenging if even suspected of an offense, however small.

\section{Obstacles to Meritocracy}

Political patronage (clientelism) and nepotism: Financial corruption is usually underground, because it is morally unaccepted. In most cases the person who take decisions based on nepotism, introduces himself as a social altruistic, not accepting the fact of liability as political supporters, family member, etc., but as it is often noted that it is the duty of the father to care for his children. This makes it even more difficult eradication.

Regarding the implementation of meritocracy criteria, it is not so clear in the state sector. Besides the political criteria, which are not only a trail of shadows left behind by dictatorships, leaders create the conditions that officials by employing different individuals, to "traffic" the private interest through appointments beyond the criteria that requires a job in an organization state. This kind of legal subjectivity also motivated by the fact that after every competition for a job in the administration, regardless of the outcome of scoring, the leader can select from a list provided to one of the persons that rank among the first three, so not the first. In the law there are lack of obligation that a decisionmaker should have to make the transparency regarding the criteria of decision in case of employement but on the other hand, deprives the right of appeal individuals, who are ranked higher in the results of the competition. Moreover, the law has no penalty to the decision-making structures in case they lose their court employees. In such conditions, it is imperative that the new law will have sanction in a very clear way as well as penalties for decision-making structures in case of wrong decisions.

Discrimination: It is ironic to note that although there is no discrimination policy, in practice they often encounter. So much talk about the role of women in decision making structures, but reality shows that it is still far from what is said. The same can be said for any social group (Roma people). As above, the appointments should practice "audited" to eliminate discrimination.

11 McCourt, 1999) 
Determination of meritocracy: A faulty definition of merit may facilitate corruption.

First, if meritocracy is defined as "to be able to do the job", while during the selection proces a lot of candidates are eligible, selectors can use the ambiguity of the results to determine their relatives or supporters against a much better candidate. It will be difficult for decisionmaker to put on his family member at work, where the skills required are precisely determined compare with another case that is not so much clear.

Politization: Meritocracy gets a bad name, if it is politicized. Often seen cases where people with integrity and professionalism, and accepted by the broad public opinion, politicized just to dampen their personality, which is contrary to the interests of those who politicize them.

\section{How to Identify Meritocracy?}

Meritocracy is not self-evident. Responsible structures often give priority to the daily ruting effects, through a system of exam-style testing university, or just based on received diplomas. Although these methods are honest and try to justify public trust, they do not know the requirements of meritocracy, because the link between what is tested and work requirements is weak and even worse, when recruited people, who do not have received basic knowledge in order to fullfill tha task.

In these conditions the psychological perspective is most appropriate, although even here there are problems. Selection sophisticated tests of personnel which are widely used in western countries, may not be suitable for developing countries, as in our case. In light of research and organizational practices, a good appointment procedure could have these elements:

1. Job analysis-written statement that will perform tasks at work (job description), requires knowledge and skills that the employer (the person specification).

2. A summary of the job analysis, which is let known to the interests group,

3. A standard application form,

4. Scoring scheme based on the specifications of the person,

5. A short listing procedure to reduce applications, if it is necessary, with candidates required.

6. A final selection procedure, based again on the person's specification and including a panel interview,

7. Appointment procedure based on the scoring scheme.

8. Notification of results to both successful and unsuccessful candidates.

Establishing an assessment center, which enables the combination of more selective methods, would be very useful in our conditions, as has been proven successful in many countries, not only for the selection of personnel to be employed in public administration, but also for career progression for employees who are already part of it. We note that staff should be selected once a year and not occasionally when policymakers may need.

Finally, Copies of relevant documentation should be retained and in case of appeal to be known to each person, especially to the public. This has to be reflected in a written document.

Modestly emphasize that the responsible structures should think seriously about undertaking the following steps:

1. Definition and public declaration that what do we mean with meritocracy,

2. To be clear about the nature and strength of the forces that are in opposition to them,

3. Auditimin existing practices to eliminate institutional discrimination,

4. Establishing appropriate institutional measures and the proper mechanisms to get feedback,

5. Establishing the best practices and procedures selection as well as appointment in public administration,

Obviously the practices of meritocracy that are highlighted are definitely universal in industrialized countries, not only in public administration but also in private companies.

All that noted, it strengthens appointments based on merit criteria. This is a simple way but very powerful, through which proper structures can improve their effectiveness reduces cases of corruption and patronage.

\section{Conclusions}

In order to institutionalizing meritocracy, a number of other institutional measures can be taken as:

a. Approval of a new public administration law,

b. Differentiation of political positions from administrative positions,

c. Appointment of an independent intellectual elite responsible for the selection of personnel in the public administration, 
d. Recruitments must be made once a year and candidates that will receive over $70 \%$ of the total evaluation score by the Standing Committee of Acceptance, are to be included in the list of winners.

Winners, starting from the top, must have the right to choose another appointment to any position free of the same group that can be free during the period of validity of the list, while the list of winning candidates, still unnamed be valid for a period of 2 years from the announcement of the winners. Such institutional measures will not abolish overnight patronage, but persistence can be used as a good basis for the expansion of merit criteria.

\section{References}

Komunikimi nga Komisioni në Parlamentin Evropian dhe Këshillin "strategjia e zgjerimit dhe sfidat kryesore 2009-2010

Draft Dokumenti Konceptual mbi mbi një ligj të ri për shërbimin civil në Shqipëri, Zhani Shaqo, Dr.Hans Achim Roll, 1 Teor 2010.

Komunikimi nga Komisioni në Parlamentin Evropian dhe Këshillin "strategjia e zgjerimit dhe sfidat kryesore 2009-2010

Draft Dokumenti Konceptual mbi mbi një ligj të ri për shërbimin civil në Shqipëri, Zhani Shaqo, Dr.Hans Achim Roll, 1 Teor 2010.

www.transparency.org

Raporti i komisionit të shërbimit civil në kuvend-mars 2012

Global Strategic Management, Philippe Lasserre, Palgrave Macmillan Limited, 2003

Krasniqi, gazeta shekulli, dt.23.08.2012

Robinson., M. (1998) 'Corruption and development: An introduction', in M. Robinson (ed.), Corruption and development. London: Frank Cass, 1-14.

Galtung, F.(1998) "Criteria for sustainable corruption control.

McCourt,W.(1999) "Paradigms and their development:The psychometric paradigm of personnel selection as a case stydy in paradigm diversity and consensus", Organization Studies (forthcoming) 